\title{
The capital structure of the enterprise as an object of management
}

\author{
Botagoz Kishibayeva ${ }^{1, *}$, Galiya Dzhaksybekova ${ }^{1}$, Arzygul Nizamdinova ${ }^{2}$, Gulnazym \\ Supugaliyeva $^{2}$ and Abay Kukiev ${ }^{2}$ \\ ${ }^{1}$ Almaty Management University, 050060, Almaty, Kazakhstan \\ ${ }^{2}$ Al-Farabi Kazakh National University, 050040 Almaty, Kazakhstan
}

\begin{abstract}
The success of any organization is largely determined by the availability of sources of capital formation, the timely completion of the need for it. Maintaining the continuity of the production process, increasing its efficiency, expanding production and creating new types of activities make it necessary to finance additional capital requirements. Modern conditions exacerbate the problem of search and informed choice of sources of replenishment of capital, and their optimal ratio is becoming increasingly important for the organization.
\end{abstract}

\section{Introduction}

The development of the Kazakhstan economy today is characterized by the uncertainty of the financial environment, in these conditions, the process of formation and optimization of capital structure. The implementation of innovative strategies requires the concentration of such an amount of financial resources that cannot be covered from own funds. Therefore, in order to carry out technological modernization, diversify the activities of the company, increase its competitiveness with the existing limitation of financial resources, the company needs to turn to the capital market in order to attract equity and debt financing. The use of these sources is not unlimited and associated with certain costs, therefore, to increase the efficiency of resource use, it is necessary to vary the share of own and borrowed capital for their most efficient use. This requires improving the policy of capital formation, taking into account not only current, but also promising goals for the development of society [1].

The capital structure is the ratio of own and borrowed funds used by the enterprise in the process of its business activities.

The conditions for the formation of such financial results of an enterprise as return on assets, return on equity, level of financial stability and solvency, level of financial risks of millers ultimately table the effectiveness of financial management as a whole depend on the capital structure, which is why the positive capital structure is an object of study for many economists.

The issue of finding the optimal capital structure, that is, such a ratio of own and borrowed funds, which ensures the most effective proportionality between the financial

\footnotetext{
* Corresponding author: botik_com@mail.ru
} 
profitability coefficient and the financial stability coefficient of the enterprise, which means its market value is maximized, has long captured the minds of many economists [2].

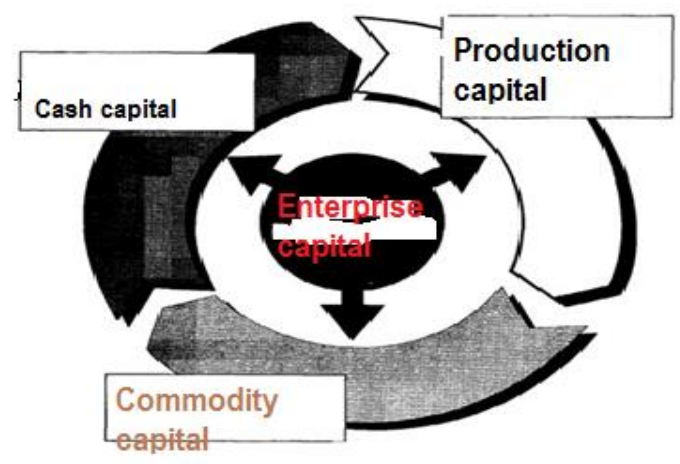

Fig.1-The nature of the movement of capital of the enterprise in the process of its circulation.

Analysis of the effectiveness of the use of own and borrowed capital of organizations is a way of accumulation, transformation and use of accounting information and reporting, with the goal:

$\checkmark$ evaluate the current and future financial condition of the separation of the organization, that is, the use of equity and borrowed capital;

$\checkmark$ substantiate the possible and acceptable pace of development of the organization from the position of providing them with sources of financing;

$\checkmark$ identify available sources of funds, evaluate rational ways to mobilize them;

$\checkmark$ to predict the position of the company in the capital market.

Analysis of the effectiveness of the use of capital of organizations is carried out using various types of models to structure and identify the relationship between the main indicators. In the current situation, descriptive models are most acceptable for analysis. At the same time, the cost of applying predicative and normative models for the analysis of the efficiency of using own and borrowed capital is not resolved [3].

Descriptive models, or models of a descriptive nature, are fundamental both for conducting capital analysis and for assessing the financial condition of an organization. These include: building a system of balance sheets; presentation of financial statements in various analytical sections; enterprise structural and dynamic reporting analysis; coefficient and factor analysis; analytical notes to reporting. All of these models are based on the use of accounting information.

Structural analysis is a set of methods for studying structure. It is based on the presentation of financial statements in the form of relative values characterizing the structure, that is, the material-intensive share (specific weight) of private indicators in the summarized total data on equity and borrowed capital is calculated.

Dynamic analysis allows you to identify trends in individual articles of equity and borrowed capital or their groups included in the financial statements [4].

Coefficient analysis is the leading method of analyzing the effectiveness of the impact of using the capital of an organization, used by various groups of users: managers, analysts, shareholders, investors, creditors, etc. 
The foundations of theoretical research on capital management were laid by A. Smith, continued by K. Marx, and developed by modern scientists such as V. V. Kovalev, B. S. Stoyanova, I. T. Balabanov, V. M. Rodionova, A. D. Sheremet, and others. the Need for capital management is due to two reasons. First, capital occupies a relatively large share of the total assets of enterprises.

It varies in the range of $20-80 \%$, depending on the industry . Accordingly, eve $\mathrm{n}$ a relativel y smal 1 reductio $n$ in the size of capital as a result of good management ca $\mathrm{n}$ resul $\mathrm{t}$ i n a noticeabl e economi c effect. Secondly, "working capital is characterized by high mobility: the stock of materials that the company had in the past has now turned into a work in progress, and new purchases are required to fill it" [5].

Certain aspects of managing current assets and sources of their financing in the framework of the organization's short-term financial policy are considered in the works Of I. A. Blank, I. L. Bykovnikov, V. V. Kovalev, V. G. Kogdatenko, M. V. Melnik, E. S. Stoyanova, I. B. Romashova, E. N. Shokhin and other authors. It is important to emphasize that there are currently disagreements and conflicting points of view in the works of scientists about the evaluation criteria and signs of aggressive and conservative models of managing current assets and their sources of financing, as well as the financial consequences of their application .

Studying the issue of optimizing the capital structure of an enterprise, it is necessary to build a step-by-step algorithm of actions to identify the optimal structure.

The algorithm consists of the following stages:

- Analysis of the capital of the enterprise;

- Assessment of factors that characterize the formation of a given capital structure;

- Ways to build the optimal capital structure of the enterprise on the principle of maximizing the level of financial profitability;

- Optimization of the capital structure of the enterprise by the method of minimizing the level of financial risks;

- The construction of the optimal capital structure by the criterion of minimizing its value;

- Formation of a strategic plan for the development of an optimal structure.

After constructing an algorithm to derive the optimal capital structure of the enterprise, we characterize each of the stages. As practice shows, often the financing policy is inadequate in accordance with the strategic development goals of the company. But at the same time, the relationship between managers and the owner or owner of the enterprise has a significant impact on business development. How, for example, the ratio of borrowed and own capital, form its structure. If the company's own funds prevail over borrowed funds, it can be concluded that an ineffective financing policy is being implemented. In the absence of guidance in the conduct of a business or enterprise, respectively, the absence of concepts on the formation of the necessary capital structure, useful so to speak for the development of the enterprise, the refusal to attract financing from the outside can cause damage to the company, which will consist in slowing down development, failure to fulfill strategic goals and objectives, the result is a discrepancy with the interests of the owner. For example, a high share of equity in the capital structure of some enterprises leads to the question of optimizing capital and building an optimal structure to further satisfy the interests of the owner [6].

There is a method of optimizing the capital structure of an enterprise by maximizing profit, which in the future leads to an optimal capital structure by maximizing the value of the enterprise and maintaining the financial position in the stability stage. This method consists in increasing profits by minimizing costs. But at the same time, the fact of the influence of capital on the level of stability of the financial indicators of the enterprise is no longer taken into account. Introducing the maximization method, it is necessary to 
remember that you need to observe the interests of the owner, which, as a rule, consists in the inflow of free profit and growth in the value of the company. The criteria for the optimal capital structure are difficult to single out, since it is also necessary to take into account the different stages of the enterprise life cycle. For example, from one stage of development to another, the capital structure formed by borrowed capital will differ from the target capital structure at another stage of development. As a result, the company will require additional costs in order to form the capital structure that meets the criteria specific to this stage of the company's development [7]. Each life cycle of a company is characterized by its own system of indicators, which describes the financial condition of the company. Due to the fact that at various stages of the company's development various goals are realized and different methods are used to achieve them, the importance of each indicator cannot be the same. Changing the priority of indicators at different stages of development, the requirements for optimality of the capital structure will also change. So the influence of the external environment affects the development of the enterprise. In a crisis, the company needs to move to a policy of reducing production volumes and reduce costs. Regardless of what stage of development the company is at, it is necessary to reevaluate the development priorities and revise the long-term development goals not only at the time of the financial crisis, but also during periods of economic growth, as these processes can lead the company to any the consequences [8].

In 1958, Franco Modigliani and Merton Miller published a work containing one of the most amazing theories of modern financial management, they came to the conclusion that the value of any company is determined solely by its future income and does not depend on the structure of its capital. This conclusion had such large-scale consequences that this work had a greater impact on the practice of financial management than all previously published comparisons.

In their work, Modigliani and Miller, on the basis of very strict given surplus conditions , including the presence of ideal capital markets, using arbitrage operations, that the capital structure does not affect the value of the company [9].

Savings due to lower tax payments increase the value of the company as the share of loans in its capital increases. However, starting from a certain point, when the share of borrowed capital increases, the value of the firm begins to decrease, since the savings on taxes are more than covered by the increase in costs due to the need to maintain a more risky structure of sources of funds [10].

Modigliani-Miller's theory, modified to take into account the cost factor of financial difficulties, States: the presence of a certain share of borrowed capital benefits the firm; excessive use of borrowed capital harms the firm ; each firm has its own optimal share of borrowed capital.

Thus, the modified Modigliani-Miller theory, called the trade-off theory between savings from lower tax payments and financial costs, allows for a better understanding of the factors that determine the optimal capital structure. Although this theory has undeniable appeal, the empirical scientific evidence for its correctness is very weak. Obviously, other factors must be taken into account when making financial decisions [11].

Based on the assumptions made by Modigliani-Miller insurance, the following rules were derived.

Table1- Modigliani-Miller Rules

\begin{tabular}{|c|l|}
\hline Rule \#1 & $\begin{array}{c}\text { The value of a firm does not depend solely on its financing } \\
\text { strategy (i.e., its capital structure): } \\
\text { VU =VL }\end{array}$ \\
\hline Rule \#2 & The expected rate of return on stocks leverageleverage (rE,L ) of \\
\hline
\end{tabular}




\begin{tabular}{|l|l|}
\hline & $\begin{array}{l}\text { the company equal to the expected rate of return on stocks } \\
\text { delivereddiovan }(\mathrm{rE}, \mathrm{U}) \text { plus a premium related to financial risk } \\
\text { equal to the debt }(\mathrm{D}) \text { to its equity }(\mathrm{E}), \text { multiplied by the difference } \\
\text { between the expected rate of return on stocks delivereddiovan firms } \\
\text { and debt: } \mathrm{rE}, \mathrm{L}=\mathrm{rE}, \mathrm{U}+(\mathrm{rE}, \mathrm{L}-\mathrm{rd}) * \mathrm{D} / \mathrm{E}\end{array}$ \\
\hline
\end{tabular}

This rule states that no matter what the distribution of capital is between debt instruments and shares, the value of assets and investments is determined solely by the assets and investments themselves. To confirm this statement, the authors of Modigliani-Miller cite the fact that investors can always replace corporate borrowing with personal financing. In this case, the company cannot do anything for the shareholders that they could not do themselves, that is, a loan does not change the value of the company [12].

Two firms in the Modigliani-Miller model, differing only in capital structure, must have the same value, otherwise the shareholders from the company with the higher price will go to the company with the lower price, which in the perfect market will equalize the value of the companies and their shares.

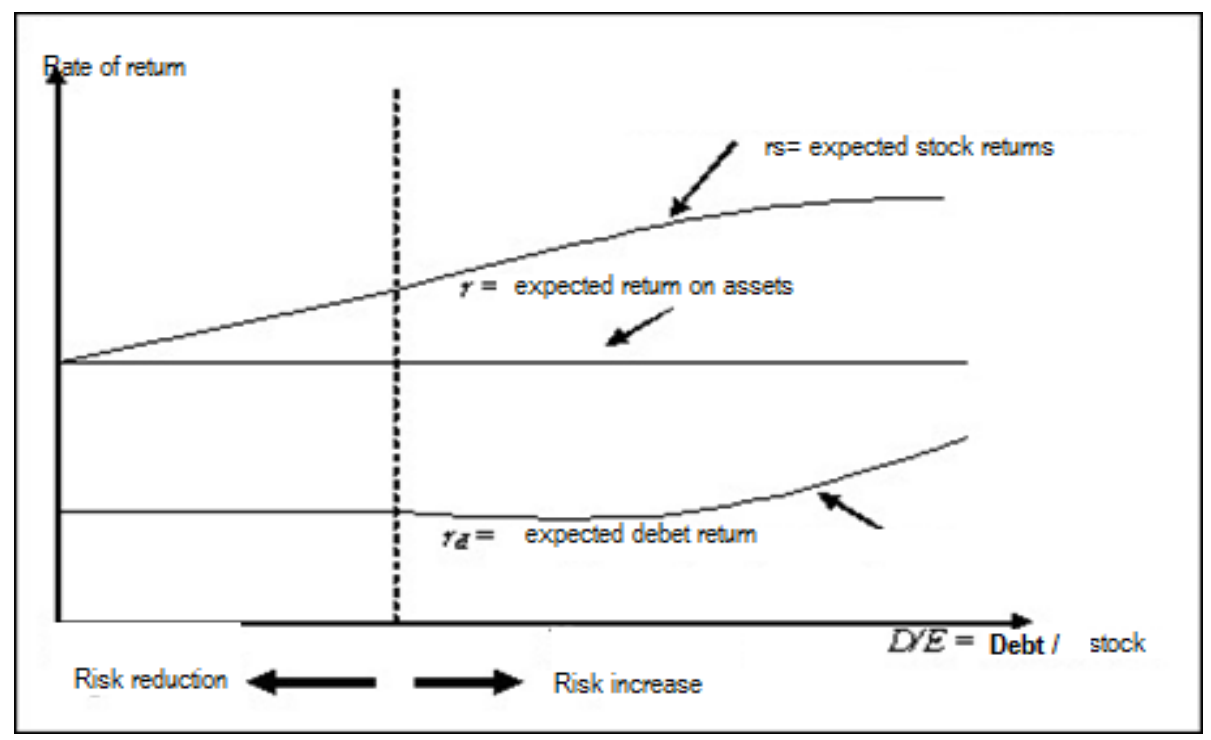

Fig.2- The general meaning of the rule of Modigliani - Miller №2

The figure is based on the assumption that the company makes additional borrowings( practically without increasing risk), while having a rather low level of debt obligations. Thus, rd is independent of D / E, and $\mathrm{rE}$ increases linearly with $\mathrm{D} / \mathrm{E}$. When a company carries out larger loans, the risk of default is increased and higher interest rates are required from the company. According to Modigliani-Miller Rule No. 2, when this happens, the growth rate $\mathrm{rE}$ decreases. This is mainly due to the fact that holders of debt obligations begin to take on part of the business risk of the company, that is, the impact of the greater the level of debt of the company, the greater part of the risk passes from shareholders to creditors. 


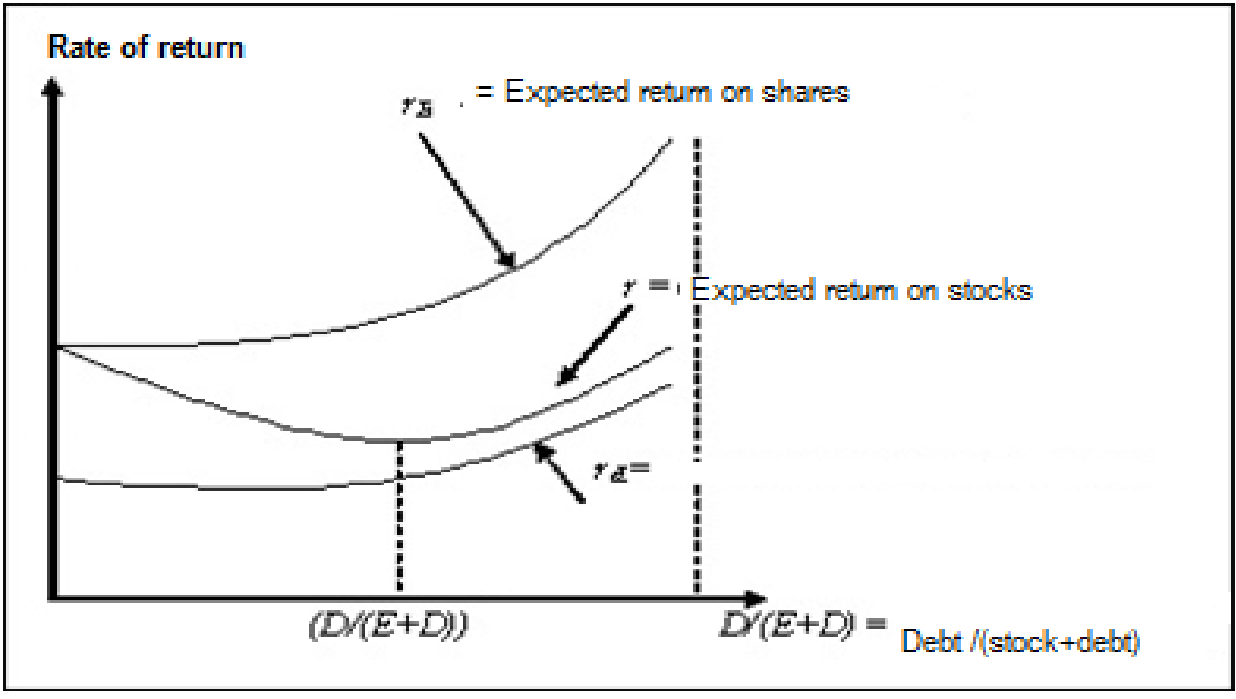

Fig.3- The ratio of the cost of equity, borrowed and total capital when taking into account corporate taxation.

Financial leverage (financial leverage) is the ratio of borrowed capital to equity, it characterizes the stability of the company. The smaller the financial leverage, the more stable the position. On the other hand, borrowed capital allows you to increase the return on equity ratio, that is, to get additional profit on equity.

The indicator that reflects the level of additional profit when using borrowed capital is called the financial leverage effect. It is calculated using the following formula

$$
E F R=\left(1-S \_n\right) \times\left(\quad K R-S \_k \quad\right) \times Z K / S K,
$$

where EFR is the effect of financial leverage, $\%$.

$\mathrm{CH}$ - income tax rate, in decimal terms.

$\mathrm{KR}$ - return on assets ratio ( the ratio of gross profit to the average value of assets), $\%$.

SK - the average interest rate for a loan, $\%$. For a more accurate calculation, you can take the weighted average rate for the loan.

$\mathrm{ZK}$ - the average amount of borrowed capital used.

$\mathrm{SK}$ - the average amount of equity.

You can make 2 conclusions:

$\checkmark$ The efficiency of using borrowed capital depends only on the ratio between the return on assets and the interest rate for the loan.

$\checkmark$ If the loan rate is higher than the return on assets, the use of borrowed capital is unprofitable.

$\checkmark$ Other things being equal, a greater financial leverage has a greater effect.

\section{Data and methodology}

To improve the efficiency of capital use ( optimizing the relationship between financial stability, price, and return on capital), the capital structure is analyzed. 
Let's consider the process of optimizing the capital structure using the method described By I. A. Blank. In accordance with this method, the attraction of additional capital, both from the company's own sources of financing and from borrowed funds, has its limits and is usually associated with an increase in its weighted average cost. To attract investors, you need to pay more income on shares or bonds when placing an additional issue.

When receiving additional loans, the value of the maximum coefficient of autonomy and, as a consequence, solvency decreases, which means that the interest rate for the loan increases due to an increase in the level of risk of bankruptcy. Similarly, when additional loans are invested in capital goods, inventory, and other low-liquid assets, the liquidity ratio decreases, which also leads to an increase in the interest rate for the loan [13].

Attracting additional loans with a high level of relative financial leverage, and therefore financial risk, is possible only under conditions of an increased interest rate for the loan, taking into account the risk premium for the Bank.

The numerical expression of the company's risk is obtained by combining the average value of the share capital and the cost of debt.

The method of forming the optimal capital structure of the enterprise makes it possible to respond in a timely manner to changes in the internal and external environment, due to the importance of indicators of the stages of enterprise development. Having stated all of the above, we can conclude that the optimization of the capital structure of the enterprise allows you to adopt and set strategic goals that will satisfy the interests of all parties, while maintaining the financial stability of the enterprise.

Formula for calculating the average weighted cost of total capital

$$
W A C C=\frac{E C}{E C+L C} * \frac{D P}{N I}+\left(1-\frac{T R P}{100}\right) *\left(\frac{L C}{E C+L C} * R C\right)
$$

where WACC is the weighted average cost of total capital,\%;

DP-amount of dividend payments, $\%$;

NI - net income, KZT RC - the level of interest rates for the loan, $\%$;

TRP-income tax rate, $\%$;

EC - own capital, tenge;

LC-borrowed capital, tenge.

For a variant with multiple sources of borrowed funds, the formula is modified accordingly. Depending on the type of total capital selected, borrowed funds are taken into account, and the amount of borrowed funds and shareholders ' equity is equal to the total capital.

Since the amount of assets is equal to the amount of liabilities or, what is the same, total capital, this means that ROA is the profitability of total capital, and WACC is its cost.

Interest on a loan in the amount of $(9,5 *$ the refinancing rate of the Central Bank of the Republic of Kazakhstan) is included in the cost of products sold (it has the property of tax protection). The remainder is paid out of the collateral's profit after income tax [14].

In addition to interest on Bank loans above the refinancing rate increased by a factor of 9,5, mandatory payments attributed by the organization to a decrease in after-tax profit include:

1 dividends on preferred shares and interest on bonds;

2 tax payments paid on profit after tax;

3 penalties to be paid to the budget and extra-budgetary funds and incurred for violation of contracts, etc. 
Formula for calculating the weighted average cost of total capital, taking into account the refinancing rate

$$
\mathrm{WACC}=\frac{\mathrm{EC}}{\mathrm{EC}+\mathrm{LC}} * \frac{\mathrm{DP}}{\mathrm{NI}}+\left(1-\frac{\mathrm{TRP}}{100}\right) *\left(\frac{\mathrm{LC}}{\mathrm{EC}+\mathrm{LC}} * 9,5 * \operatorname{RefR}\right)+\frac{\mathrm{LC}}{\mathrm{EC}+\mathrm{LC}} *(\mathrm{RC}-9,5 * \operatorname{RefR})
$$

where RefR-refinancing of the Central Bank of Kazakhstan, \%

DP-amount of dividend payments, $\%$;

NI-net profit, tenge

$\mathrm{RC}$ - the level of interest rates for the loan, \%;

TRP-income tax rate, $\%$;

EC - own capital, tenge;

LC-borrowed capital, tenge

To improve the efficiency of capital use (optimizing the relationship between financial stability, price, and return on capital), the capital structure is analyzed.

The return on equity depends on the ratio of equity to debt, return on assets, income tax rate, and the ratio of the loan rate to return on assets.An increase in the share of borrowed funds provides an increase in the return on equity, provided that the return on assets is higher than the interest rate on credit resources, taking into account the tax corrector. But at the same time, it is necessary to take into account that when the share of debt financing increases, not only the profitability, but also the risk of shareholders increases.

Formula used to maximize return on equity

$$
R O E=\left(1-\frac{T R P}{100}\right) * R O A *\left(1+\frac{L C}{E C} *\left(1-\frac{R C}{R O A} *\left(1-\frac{T R o}{100}\right)\right)\right)
$$

(4)

where ROE is return on equity, $\%$;

TRP-income tax rate, $\%$;

ROA-return on assets, \%;

RC-the rate level for the loan, \% (according to the DUO);

EC - own capital, tenge;

LC-borrowed capital, tenge

LC/EC-share of borrowed capital, tenths;

Comparing ROE with ROA shows the impact of debt capital on shareholder returns. For a more accurate calculation, it is necessary to take into account that if the rates on loans exceed 9,5* $\mathrm{R}$ of the Central Bank of Kazakhstan refinancing, the calculation is made taking into account the fact that the interest on the loan exceeding $1.1 *$ RREF will not have the property of protection from income tax. profitability Please note that the refinancing rate should be the one that was in effect on the day the loan was received, not the one that is valid in the period for which interest is accrued [15].

The formula used to maximize the return on equity taking into account the refinancing rate of the 


$$
\mathrm{ROE}=\left(1-\frac{\mathrm{TRP}}{100}\right) * \mathrm{ROA} *\left(1+\frac{\mathrm{LC}}{\mathrm{EC}} *\left(1-\frac{9,5 * \mathrm{RefR}}{\mathrm{ROA}} *\left(1 * \frac{\mathrm{TRP}}{100}\right)-\frac{\mathrm{RC}-9,5 * \mathrm{RefR}}{\mathrm{ROA}}\right)\right)
$$

where RefR is the refinancing rate of the Central Bank of Kazakhstan, \%; TRP-income tax rate, \%;

ROA-return on assets, \%;

RC-the rate level for the loan, \% (for the DUO));

$\mathrm{LC} / \mathrm{EC}$ - share of borrowed capital, tenths.

\section{Results and discussion}

In his speech at the solemn meeting dedicated to the Independence Day of the Republic of Kazakhstan, President Nursultan Nazarbayev identified the most important priorities of our domestic and foreign policy [16]. Acceleration of the process of transition of all legal entities to international financial reporting standards is indicated as one of the directions. In accordance with this priority, practicing accountants of legal entities of all organizational and legal forms must correctly transform the company's accounting data that reflect the company's assets and sources of their formation. When considering this issue, different concepts arise - equity, attracted capital, active capital, and passive capital [17].

In modern conditions, the capital structure is a factor that has a direct impact on the financial condition of the organization - its solvency and liquidity, the amount of income, and profitability. The structure of the organization's sources of funds is evaluated by both internal and external users of accounting information. External users (banks, investors) assess the change in the share of the organization's own funds in the total amount of funds sources from the point of view of financial risk when concluding transactions. Internal analysis of the capital structure is related to the assessment of alternative financing options for the company's activities.

As a result of the study, it was found that the capital of enterprises is cash held in revolving funds, circulation funds and other assets. In a market economy, the financial and economic condition of a company largely depends on the state and effectiveness of capital use.

The formation of the capital structure of any commercial organizations is directly related to their financing. Determining the capital structure that is optimal for specific economic conditions in a particular time period, financial managers of the company evaluate the cost and price of attracted sources of financing, calculate the estimated costs and profitability of investments in the development of the enterprise.

Assessing the financial stability of insurers allows you to identify important quantitative parameters of activity, their strengths and weaknesses, outline ways to solve problems. When using the methodology for assessing the financial stability of the insurer, it is necessary to develop a set of indicators. The wider the set of indicators, the more reliable and reasonable the conclusion about the financial position of the insurance company. However, the multiplicity of unequal indicators complicates the practical use of the methodology [18].

The formation of a rational structure of sources of funds usually proceeds from the most general target: to find the ratio between borrowed and own funds that ensures the most efficient proportionality between the financial profitability coefficient and the financial stability coefficient of the enterprise, i.e., its market value is maximized. The process of optimizing the capital structure of an enterprise is carried out at certain stages. To form a 
rational capital structure, it is necessary to analyze the efficiency of capital use and the rationality of its structure.

Thus, the "Cash Flow Plan" is an important document that allows you to determine the need for capital and serves to assess the efficiency of capital use [19]. For example, we calculate various options for a financial capital management strategy based on the data in table 2 .

Table 2 - Option of money management strategy, mln. Tenge

\begin{tabular}{|c|c|c|c|c|c|}
\hline Month & $\begin{array}{c}\text { Current assets } \\
\text { (forecast) }\end{array}$ & Fixed assets & Total assets & $\begin{array}{c}\text { Minimum } \\
\text { need for } \\
\text { sourse }\end{array}$ & Seasonal need \\
\hline January & 15 & 60 & 75 & 68 & 7 \\
\hline February & 14 & 60 & 74 & 68 & 6 \\
\hline March & 15 & 60 & 75 & 68 & 7 \\
\hline April & 13 & 60 & 73 & 68 & 5 \\
\hline May & 11 & 60 & 71 & 68 & 3 \\
\hline June & 11 & 60 & 71 & 68 & 3 \\
\hline July & 8 & 60 & 68 & 68 & 0 \\
\hline August & 10 & 60 & 70 & 68 & 2 \\
\hline September & 13 & 60 & 73 & 68 & 5 \\
\hline October & 16 & 60 & 76 & 68 & 8 \\
\hline November & 14 & 60 & 74 & 68 & 6 \\
\hline Desember & 14 & 60 & 74 & 68 & 6 \\
\hline
\end{tabular}

Thus, the systematic part of current assets represents the minimum need for working capital and is equal to 8 million tenge (as of July). The minimum need for sources of funds is equal to 68 million tenge in June, the maximum - 76 million tenge in October. The first line characterizes an aggressive strategy in which long-term liabilities cover non-current assets and the system part of current assets. In accordance with this strategy of the enterprise, its long-term liabilities should amount to 68 million tenge. The remaining need for funding sources is covered by short-term accounts payable. In this case, the net working capital will be 8 million tenge. The second line characterizes a conservative strategy, according to which long-term liabilities are maintained at the maximum necessary level, i.e. in the amount of 76 million tenge. In this case, the net working capital will be 16 million tenge. The third line characterizes a compromise strategy, according to which long-term liabilities are set in the amount covering non-current assets, the system part of current assets and half the forecast value of the variable part of current assets, i.e. in the amount of 72 million tenge. In this case, the net working capital will be 12 million tenge. Thus, the stated problems show that when managing capital, a careful study of the financial and economic nature of the phenomena under consideration, a clear knowledge of the system for reflecting financial and economic operations in accounting, regulated by accounting standards, are required [20].

\section{Conclusion}

Thus, in the process of managing the capital structure, companies usually proceed from the most general target: to find the ratio between borrowed and own funds at which the value of the company's share will be the highest. This, in turn, becomes possible with a sufficiently high, but not excessive effect of financial leverage. The debt level serves as a sensitive market indicator for the investor's well-being. The extremely high share of borrowed funds in liabilities indicates an increased risk of bankruptcy [21]. When an enterprise prefers to manage with its own funds, the risk of bankruptcy is limited, but investors receiving 
relatively modest dividends believe that the company does not pursue the goal of maximizing profits and begin to dump shares, reducing the market value of the enterprise. So, for mature, long-running companies, a new issue of shares is usually regarded by investors as a negative signal, and borrowing as a favorable or neutral one. This is an argument in favor of the fact that the company should not fully use its borrowed ability; it is necessary to maintain a reserve of financial flexibility in order to always be able to attract loans and loans on acceptable terms [22].

Based on the foregoing, a decision on the use of various sources of financing should be made within the framework of the selected financial policy of the company based on the tasks it solves, management structure, the nature of long-term and operational planning, and a number of other factors, including internal ones (sales growth rate, stability of dynamics sales, the level and dynamics of profitability, the current structure and liquidity of assets, the strategy and financial guidelines for future development) and external (short-term market conditions and debt term credit resources, the tax burden, the relationship with potential lenders and etc.) [23].

\section{References}

1. A.S. Jondelbayeva, Optimization of stock company's equity structure as the way to increase investment attractiveness, Almaty 2016

2. G.N. Dzhaksybekova company Value: theory and practice of valuation in the financial sector management. Monograph. - Astana: BERKUT - Print LLP, 447 (2011)

3. G.N. Dzhaksybekova Capital of the company: structure, optimization and cost. Collective monograph of the Department "Finance" for the 50th anniversary of KazEU.T. Ryskulova. - Almaty: Ekonomika, (2013)

4. M. Tkachuk, E.Kireeva Fundamentals of financial management. - Minsk.: Ecoperspective, 416 (2011)

5. Maslenkova O.F. Ocenka stoimosti predprijatija (biznesa). Uchebnoe posobie. M.: KNORUS, 288 (2015)

6. Il'in V.V., Serdjukova N.A., Alekseev V.N., Ermilov V.G. Finansovyj menedzhment. uchebnik pod red. Il'ina V.V. - M.:Izdatel'stvo« Omega-L», 560 (2014)

7. Blank I.A. Konceptual'nye osnovy finansovogo menedzhmenta: Jenciklopedija finansovogo menedzhera. - M.:Omega-L, 448 (2013)

8. Brejli R., Majers S. Principy korporativnyh finansov. - 2-e izdanie. - M.: ZAO «Olim-biznes», 977 (2014)

9. A.A.Kanke, I.P. Koshevaya Analysis of financial and economic activity of the enterprise: a textbook. - Moscow: Infra-M, 288 (2014)

10. V.V. Kovalev, O.N. Volkova Analysis of economic activity of the enterprise: textbook. - M.: unincorporated business, 432 (2011)

11. S.I. Lutsenko Balance of interests between participants in the formation of the financial structure of the company's capital/ S.I. Lutsenko / / Financial management, 73 (2013) - No. 5

12. G.V. Savitskaya Analysis of economic activity of the enterprise: a textbook. Meganewton.: New knowledge, 688 (2008)

13. V.V. Kovalev Introduction to financial management. - Moscow: Finance and statistics, 302 (2012)

14. A.F. Ionova, N.N. Selezneva Financial management. - Moscow: Prospect, 592 (2014)

15. Form I. a Financial management: studies. Course. - K.: Nika-Center, 471 (2013) 
16. I. Levchuk Modern systems of business capital management / / Small business, 79 (2014)- No.2

17. E. YU. Klyueva, Capital structure as an object of management in the financial management system

18. Ziyadin, S.; Shash, N.; Levchenko, T., Khudaibergenova, S.; Yessenova, G. Entrepreneurship and Sustainability Issues 6(4): 2180-2193. 2019. http://doi.org/10.9770/jesi.2019.6.4(43)

19. Saakova E.B., Saakova A.S., Bartkova N.N. Optimization of the organization capital STRUCTURE AS AN ANTI-CRISIS MANAGEMENT TOOL

20. Teplova T.V. Financial management: capital and investment management, etc. M.: HSE, 2000. 504 p.

21. Speech of the President of the Republic of Kazakhstan N. A. Nazarbayev at the solemn meeting dedicated to the Independence Day of the Republic of Kazakhstan

22. Baranov V.V. Financial management. Mechanisms for financial management of enterprises in traditional and high-tech industries. M .: Delo, 2002.272 s.

23. Financial accounting at the enterprise / Ed. R. M. Rakhimbekova - Almaty: Economics, 2012 .-- 420 p. 